\title{
Cholecystectomia során bekövetkező epeútsérülések ellátása
}

\section{Treatment of bile duct injuries during cholecystectomy}

\author{
KECZER BÁNK ${ }^{@}$, CSUJA NÁNDOR MIKLÓS, FÜLÖP ANDRÁs, PEKLI DAMJÁN, \\ HARSÁNYI LÁSZLÓ, HRITZ ISTVÁN, SZIJÁRTÓ ATTILA \\ Semmelweis Egyetem, I. sz. Sebészeti Klinika, Budapest \\ (klinikavezető: dr. Szijártó Attila)
}

\begin{abstract}
A laparoszkópos cholecystectomia (LC) a leggyakrabban végzett mütétek egyike. A beavatkozás ritka, ugyanakkor nagyon súlyos szövődménye az epeúti sérülés. Célunk az LC, valamint laparoszkópos kezdés után konvertált mütétek során bekövetkezett epeúti sérülések és szövődményeik, valamint ezek ellátásának vizsgálata volt.

Vizsgálatainkat a Semmelweis Egyetem I. sz. Sebészeti Klinikáján 2006-2016 között epehólyag-eltávolításra került betegek dokumentációjának retrospektív elemzésével végeztük.

Tizenegy év alatt 4885 cholecystectomiát végeztünk. Ebböl 4558 (93,3\%) laparoszkópos mütét, melyböl 30 betegnél fordult elő valamilyen szövődmény, ami az összes LC 0,66\%-a. A konvertált mütétek közül 7,95\%-ban (26/327) lépett fel szövődmény. Más intézményből 22 szövődményes beteget utaltak Klinikánkra. Epeút-, illetve érsérülés 41 esetben fordult elő $(61 \%, 41 / 78)$. Epeúti sérülés ellátása során 25 esetben került sor epeúti intervencióra (ERCP), 92\%-os siker aránnyal. Reoperációra az epeúti sérült betegek $68 \%$-nál volt szükség (28/41), melynek során a végleges epeúti rekonstrukció $82 \%$-ban hepaticojejunostomia segítségével történt.

Következtetés: A laparoszkópos cholecystectomia a XXI. században is rutin beavatkozásának tekinthető, ugyanakkor a szövődmények terápiás megoldása továbbra is nehéz. A szövődményes esetek ellátása csak nagy gyakorlatú, multidiszciplináris háttérrel rendelkező intézményekben javasolt.
\end{abstract}

Kulcsszavak: epeúti sérülés, laparoszkópos cholecystectomia, posztoperatív szövődmények

Biliary injury is a rare but a very serious complication of laparoscopic cholecystectomy (LC). Our aim was to analyse the incidence of the biliary injuries and its therapeutic outcome on patients who underwent LC or converted LC.

Our research was conducted at the 1st Department of Surgery, Semmelweis University, Budapest between 2006 and 2016, retrospectively. We analysed the LCs and converted LCs performed at our Department and as well as cases where the primary operations were conducted at other institutions but they were unable to provide the adequate therapy for the injury, thus the patients were transferred to our institution.

At the 1st Department of Surgery complications occurred in 0,66\% (30/4885) of all LCs. 327 converted LCs were done, complications occurred in $26(7.95 \%)$ times. 22 patients were transferred to the 1 st Department of Surgery from other institutions. Bilio-vascular injuries occurred in 61\% (41/78). ERCP was performed in 25 cases with a $92 \%$ success rate. Reoperation was needed in $41 \%(28 / 41)$. Biliary reconstruction during the reoperation was performed via hepaticojejunostomy in $82 \%$ of all reoperations.

The therapeutic solutions of LC's complications are complex. Therefore, the treatment is recommended only in institutions with appropriate experience.

Keywords: bile duct injury, laparoscopic cholecystectomy, postoperative complications

Beérkezett: 2020. május 28.; elfogadva: 2020. június 15.

\section{Bevezetés}

A laparoszkópos cholecystectomia (LC) az egyik leggyakrabban végzett sebészeti beavatkozások egyike világszerte.
Gyakorisága ellenére ma is azon eljárások közé tartozik, amelyek súlyos, hosszú kihatású szövődményekkel járhatnak. Egy nagy nemzetközi tanulmány első olvasatra megdöbbentő adatai alapján a 30 napos posztoperatív mor-

\footnotetext{
@Levelezési cim/Corr. address: Dr. Keczer Bánk, 3700 Kazincbarcika, Erdész utca 13.,Tel.: 06-20-663-2223, E-mail: keczer45@gmail.com
} 


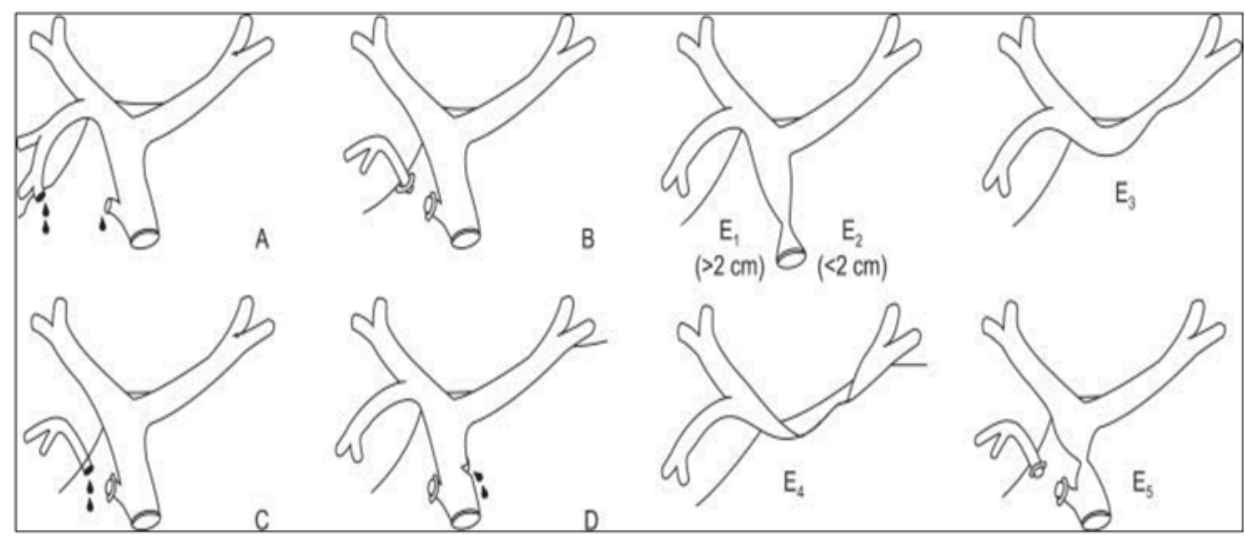

1. ábra. A Strasberg féle klasszifikáció. (A) Epeszivárgás a ductus cysticus csonkból vagy a epehólyag-ágyi kis ágakból. (B) Elzáródott jobb hátsó ductális ág. (C) Epeszivárgás a jobb hátsó ductális ágból. (D) Epecsorgás a ductus hepaticus communisból. (E1) Átvágott föepe-vezeték, rajta szükülettel a hilustül több, mint 2cm-re, (E2) esetén kevesebb, mint 2cm-re. (E3) Hilusi szükület a kommunikáló jobb, illetve bal ductusokkal. (E4) Hilusi szükület elválasztott jobb, illetve bal ductusokkal. (E5) A főepevezeték és a jobb hátsó ductalis ág szükülete

biditás 9,84\%-ra tehető. Habár mind a képzésben, mind a napi gyakorlatban kiemelt törekvés, hogy a mütéti szituáció, lépések, döntési pontok standardizáltak legyenek (pl. critical view of safety, SAGES guidelines), sajnos a mütét ritka, ugyanakkor nagyon súlyos szövődménye az epeúti sérülés, melynek hosszú távon is eredményes ellátását a legnehezebb posztoperatív kihívások között tarthatjuk számon. Az epeúti sérülés előfordulása az irodalmi adatok szerint körülbelül $0,1-2,0 \%$-ra tehető. ${ }^{1-3}$

Az epe- és érsérülések tekintetében számos klasszifikáció látott napvilágot. Elsőként, 1982-ben Bismuth osztályozta az epeúti sérüléseket. A lézió lokalizációja alapján 5 csoportot különböztet meg. McMahon és munkatársai a sérülés szélessége alapján minor és major csoportokat különböztettek meg. A Bismuth és a McMahon klasszifikációkkal szemben a Stewart-Way-féle rendszer már az esetlegesen társuló érsérüléseket is számba vette. A Mattox-klasszifikáció ezek mellett figyelembe veszi a sérülés körülményeit (zúzódás, laceráció, perforáció, transszekció) is. A fentieken túl széles körben elterjedt még a Bektas és munkatársai által javasolt Hannoveri klasszifikáció is, ami a bifurkáció alatt és fölött elhelyezkedő sérülések esetében megkülönböztet érintőleges vagy teljes haránt léziót, valamint számol az esetleges érsérülésekkel is. ${ }^{4}$

A Bismuth-féle beosztás módosítása a Strasberg-féle rendszer, amely talán a legkönnyebben alkalmazható és az irodalmi adatok alapján a legszélesebb körben elterjedt osztályozási rendszer az epeúti sérülésekre. Jóllehet a klaszszifikáció az esetleges érsérüléssel nem számol (1. ábra). ${ }^{4}$

Az epeúti sérülés elhelyezkedése, kiterjedésének mértéke és diagnózisának ideje meghatározhatja a terápiás kimenetelt. A sérülés felismerése és helyreállítása bekövetkezhet már a primér mütét kapcsán is, de gyakran a szövődményre csak a mütét után derül fény, így újbóli intervencióra (minimál invazív endoszkópos beavatkozás), vagy akár reoperációra is sor kerülhet. A sérülés komplexitása miatt, a rekonstrukció kimenetelét több tényező is meghatározhatja. A szövődmények ellátása multidiszciplináris együttműködést és nagymértékü szakmai tapasztalatot igényel. ${ }^{4}$

\section{Célkitüzés}

Célunk az LC, valamint laparoszkópos kezdés után konvertált mütéten átesett betegek mütéti szövődményeinek, különösképpen az epeúti sérüléseknek, illetve ezek ellátásának vizsgálata volt.

\section{Betegek és módszerek}

A 2006 és 2016 között vizsgált betegcsoport két részből adódott össze. Egyik részét a Semmelweis Egyetem I. sz. Sebészeti Klinikáján operált betegek alkották, másik ré-

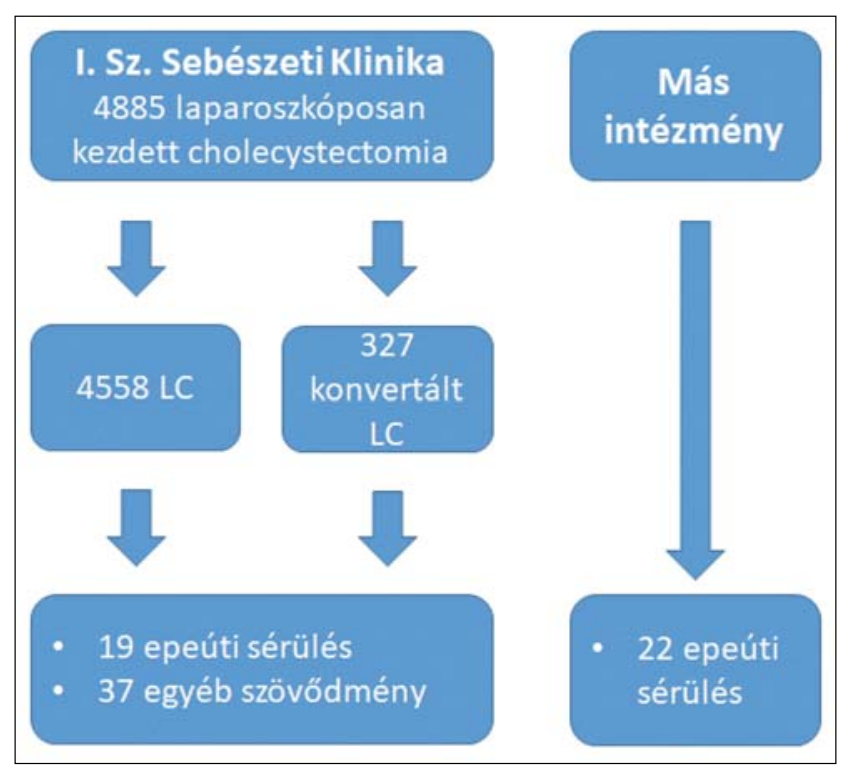

2. ábra. A beteganyag megoszlása 
szében az epehólyag-eltávolítás más intézményben történt, de a kialakult szövődmény helyben nem került ellátásra, így a progresszív ellátás keretében klinikánkra helyezték át a beteget (2. ábra).

Vizsgált paramétereink között voltak a demográfiai és antropometriai adatok. Elemeztük a cholecystectomia javallatait és az operatőr jártasságát. Utóbbit illetően arra voltunk kíváncsiak, hogy volt-e különbség a szövődmények gyakoriságában annak függvényében, hogy a mütétet nem szakorvos, fiatal szakorvos (kevesebb mint 5 éve szakorvos) vagy tapasztaltabb szakorvos (több mint 5 éve szakorvos) végezte.

A mütéti szövődményeket két csoportra osztottuk. Az egyik csoportot az epeút- és érsérülések alkották, míg a másikat az egyéb szövődmények. Elöbbi alatt azokat az iatrogén epeúti, valamint epeúti régiót (a ligamentum hepatoduodenale érképletei) érintő érsérüléseket értettük, amelyek további intervenciót vagy sebészeti beavatkozást igényeltek. Az egyéb szövődmények csoportjába tartozott minden olyan szövődmény, amely nem az epeutakat, illetve a ligamentum hepatoduodenale ereit érintette (sebfertőzés, májtályog, ileus, szepszis, peritonitis). Mivel érsérülés mint később bemutatásra kerül - vizsgálatunk során csak elhanyagolható számban fordult elő, így választásunk az epeúti sérülések osztályozására a Strasberg-féle klasszifikáció alkalmazására esett.

Az epeúti sérülés felismerésének idejét és módját vizsgálva elemeztük, hogy a szövődmény felismerése a primer mütét során történt-e meg, vagy csak azt követően. Előbbi esetben történt-e primer rekonstrukció, utóbbi esetben pedig azt, hogy hány nap telt el a primer beavatkozás és a szövődmény felismerése, valamint ellátása között (korai, tehát egy héten belüli versus késői reoperáció) illetőleg, hogy milyen módon történt a sérülés ellátása (endoszkópos beavatkozás vagy perkután transzhepatikus intervenció vagy mütét), és mi volt a beavatkozások kimenetele.

\section{Eredmények}

A Semmelweis Egyetem I. sz. Sebészeti Klinikáján 20062016 között 4885 laparoszkópos indítású epehólyageltávolítás történt. Ebböl 4558 (93,3\%) beavatkozást laparoszkóposan fejeztünk be (ami átlagosan évi 414 mütétet jelent), $327(6 \%, 327 / 4885)$ esetben történt konvertált cholecystectomia (ami átlagosan évi 30 konverziót jelent). A Klinikánkon vizsgált 4885 eset közül 0,3\%-ban (19/4885) lépett fel epeúti sérülés, míg az egyéb szövődmények előfordulása $0,7 \%(37 / 4885)$ volt.

További 22 beteget utaltak a klinikánkra más intézményből, a primer mütét során fellépett epeúti sérülés ellátása céljából. Így összesen 78 eset mütéti körülményeit elemeztük, amelyet a 41 epeúti sérülés és a 37 egyéb szövődmény alkotott (2. ábra).

A 78 beteg $68 \%$-a $(53 / 78)$ nő és $32 \%$-a $(25 / 78)$ férfi, a betegek átlagéletkora 55,4 év volt. A nők esetében ez 53,1 évnek, a férfiaknál 60,0 évnek adódott. Body Mass
Index (BMI) alapján „túlsúlyos” (BMI: 25-29,9) betegek 32\%-ban fordultak elö, „elhízott” (BMI: >30) betegek az esetek $21 \%$-át adták. Ez azt jelenti, hogy a szövődményes betegek 53\%-nak a testtömegindexe kóros volt.

Az I. sz. Sebészeti Klinikán végzett szövődménnyel járó LC-k esetében 73\%-ban elektív mütét történt. Azon betegek esetén, ahol a primer mütétet másik intézményben végezték, az elektív mütétek aránya $82 \%$ volt.

A szövődményes cholecystectomiák javallatainak 74\%ában (58/78) epehólyagkövesség állt a háttérben. Huszonhárom százalékban (18/78) acut cholecystitis miatt történt a primer mütét, egy esetben akut biliaris pancreatitis, valamint szintén egy betegnél epehólyagpolyp volt a mütéti javallat.

Az operatőrök jártassága alapján felállított 3 csoport vizsgálata során azt tapasztaltuk, hogy az egyes csoportok között a szövődményes esetek közel azonos számban fordultak elő. A szövődményes esetek 26\%-át végezte nem szakorvos, 39\%-át fiatal szakorvos és 35\%-át tapasztalt szakorvos.

A 78 szövődményes esetböl 46 esetben LC, míg 32 esetben konvertált LC történt. A 41 epeút- és érsérülést elszenvedett beteg közül 13 esetben történt konverzió. Tíz esetben az epeúti sérülés miatt, míg a maradék 3 esetben a kiterjedt hasi összenövések miatt. Az epeúti sérülések 24\%-ában (10/41) került a lézió, a primér műtét kapcsán, intraoperatívan felismerésére. A kétes szituációk tisztázására 3 esetben alkalmaztak intraoperatív cholangiographiát a diagnózis megerősítéséhez. A maradék 31 beteg esetében az epeúti vagy érlézió csak a mütétet követően került felfedezésre. A posztoperatív diagnózisra az esetek túlnyomó többségében epés drainhozam hívta fel a figyelmet. Valamennyi epeút- és érsérülés diagnózisa 7 napon belül történt.

Nem epeúti és érsérülést jelentő egyéb szövődmények az I. sz. Sebészeti Klinikán 0,7\%-ban (37/4885) fordultak elő. Ezek 46\%-át (17/37) tette ki a sebfertőzés (surgical site infection), ami gyakrabban fordult elő konvertált esetekben $(76 \%, 13 / 17)$. Reoperációt szükségessé tevő hasfalszétválás, illetve kiterjedt lágyrészgyulladás (fascia necrosis) nem következett be. Posztoperatív májtályog (főleg az epehólyagágyra lokalizálódva) az egyéb szövődmények 5\%-át (2/37) alkotta, mely esetekben ultrahang vezérelt drainage jelentette a megoldást. Ileus 5\%-ban (2/37) jelentkezett, minden esetben reoperációt téve szükségessé. Egy esetben strangulatiós ileust találtunk, míg a másik esetben mechanikus akadály nem volt kimutatható, a paralysist egyéb okok (lokális peritonitis, ionháztartás zavara) magyarázták. Szepszis és peritonitis mindösszesen 4 esetben fordult elö, ebből 3 eset kapcsán a konzervatív terápia (antibiotikum-kúra) elégségesnek bizonyult, mütéti beavatkozásra nem került sor. Az egyik peritonitises eset ileussal társult, amely indokolta a laparotomiát, melynek során az állapot hátterében bélnecrosist találtunk (strangulatio).

Az esetek 32\%-ában (12/37) fordult elő, egyéb szövődmény, melyek közül pneumonia, pyelonephritis, mellkasi 


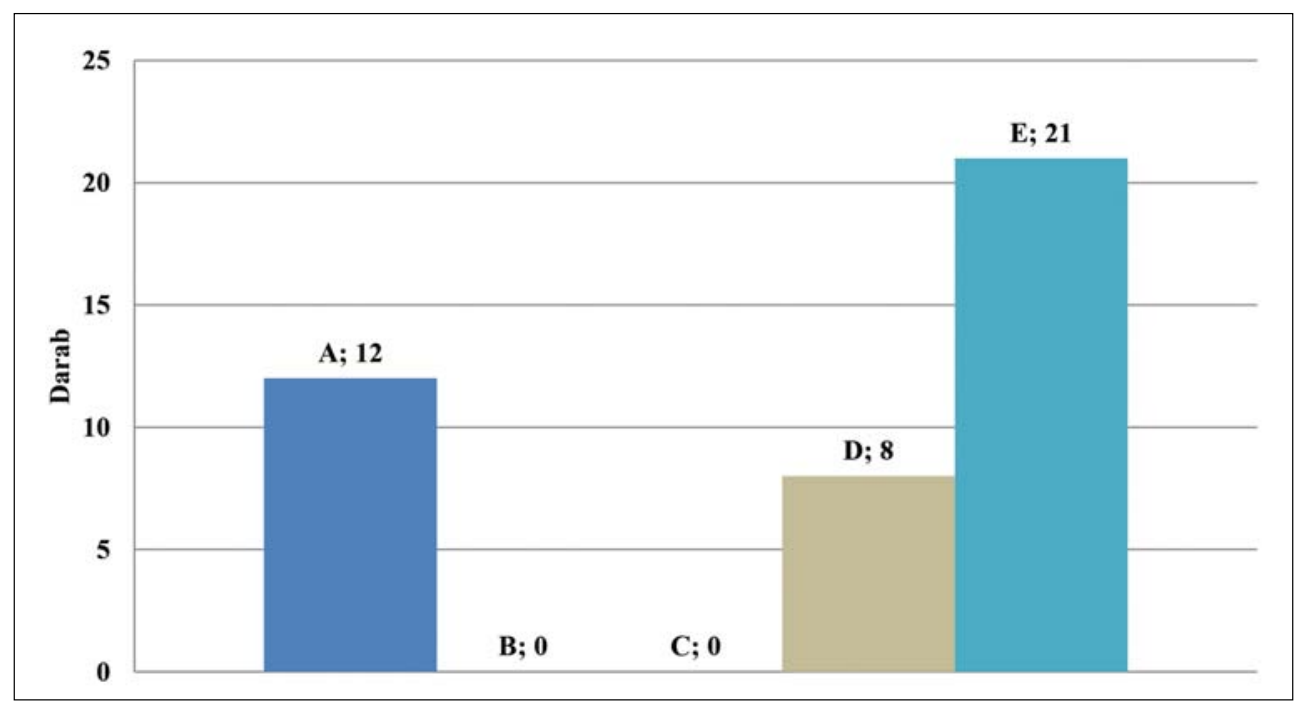

3. ábra. Az epeúti sérülések megoszlása a Strasberg-féle klasszifikáció alapján

folyadékgyülem, mélyvénás thrombózis, pancreas pseudocysta, valamint Clostridium difficile-fertőzés emelendők ki.

LC vagy konvertált LC során a 78 szövődményes eset közül 41 betegnél következett be epeúti sérülés, melyek közül egy beteg esetén pedig érsérülés is bekövetkezett, amely a jobb oldali artéria hepaticát érintette. Egy esetben fordult elö posztoperatív vérzés az arteria cystica csonkja felől. Tizenkét eset mögött (29\%) Strasberg „A” típusú epeúti sérülés állt. A „B”, illetve „C” csoportokba egy eset sem került, míg a „D” csoportba 8 darab (20\%) epeúti lézió volt besorolható. Az epeúti sérülések több mint a fele az „E” csoport, különböző alcsoportjaiba tartozott, ez 21 föt (51\%) takart. A legtöbben, 10-en az „E2”-es alcsoportba tartoztak. Ezt követte 6 fővel az „E1”-es csoport, majd 4 fóvel az „E3”-as és végezetül 1 fóvel az „E4”-es csoport (3. ábra).

Összesen a 41 betegen 47 mütét történt, az epeúti sérülés helyreállítása céljából, illetve a másodlagos szövőd- mények ellátása miatt. A mütéti beavatkozások során megkülönböztettünk a sérüléssel együlésben történő, primér $(21 \%, 10 / 47)$ epeúti rekonstrukciót, valamint halasztott helyreállítást $(79 \%, 37 / 47)$.

Klinikánkon 19 esetben történt epeúti sérülés, melyből 5 esetben történt együlésben rekonstrukció. Ebböl intraoperatívan, a primér mütét során 3 hepatico-jejunostomia, 1 Kehr-drainage és 1 a ductus hepaticus communist érintő sutura történt. Egyik esetben se volt szükség reoperációra. A posztoperatív diagnosztizált epeúti sérülések ellátása tekintetében 2 Kehr-drainaget végeztünk, amelyek közül egy esetben újabb intervenció, ERCP-s stent implantáció is szükséges volt. Egy eset során az epehólyagágy suturázása jelentette a végső megoldást. Az epeúti sérülés diagnózisa után 11 ERCP-t végeztünk stentbehelyezéssel. Két esetben a stentimplantáció se szüntette meg az epecsorgást, 1 esetben Kehr-drainage, 1 másikban pedig a ductus cysticus lekötése követte az endoszkópos beavatkozást. Egy

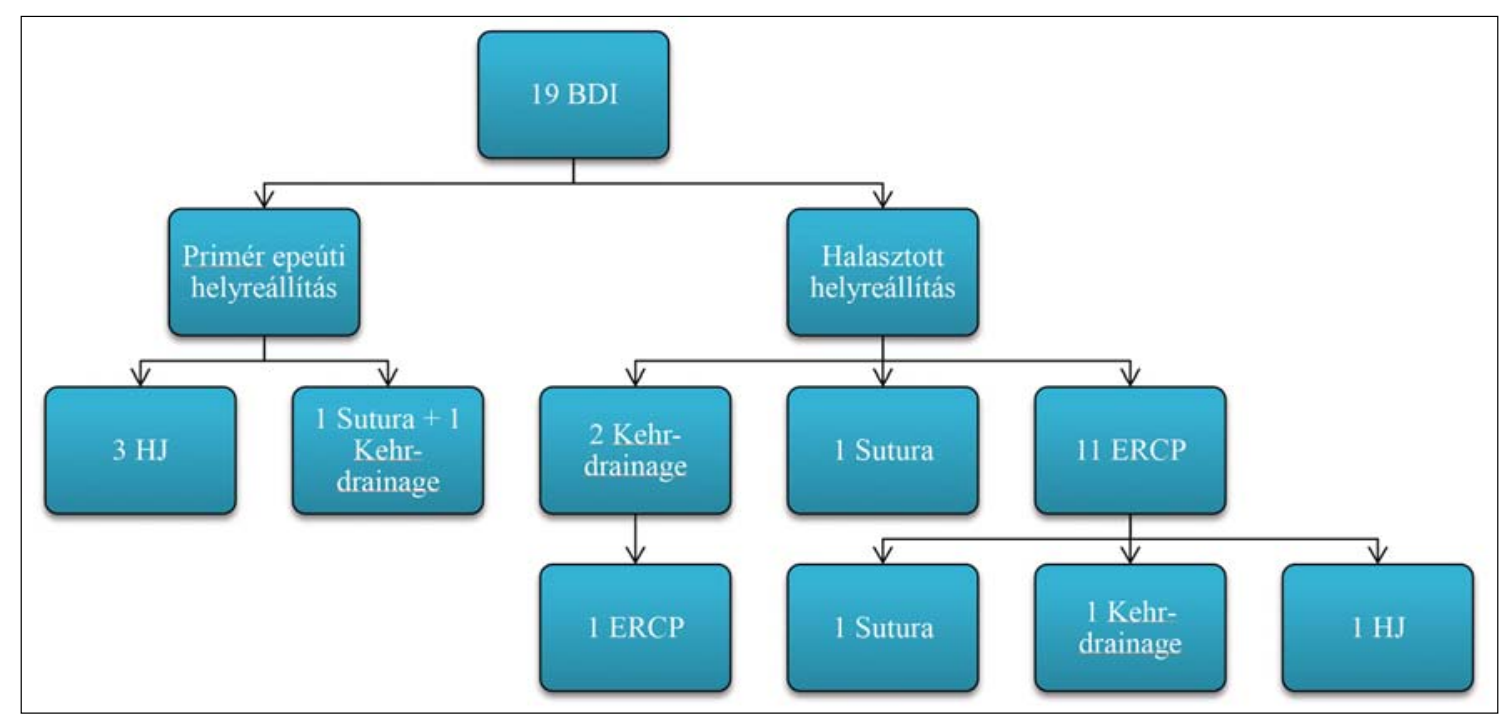

4. ábra. A munkahelyünkön fellépő epeúti sérülések ellátása 
további esetben a stent behelyezése is sikertelen volt, így reoperációra szorultunk hepatico-jejunostomia formájában (4. ábra).

A más intézményben vétett 22 epeúti sérülés esetében szintén 5 alkalommal történt rekonstrukció a primér mütét során. Két esetben hepatico-jejunostomiát végeztek, három esetben pedig intraoperatívan Kehr-drainage készült. Később mind az előbb említett 5 esetben reoperáció vált szükségességé, amely során hepatico-jejunostomia vagy a már meglévő biliodigestív anastomosis korrekciója történt. Egy esetben diagnosztikus ERCP-vizsgálat is történt stentimplantáció nélkül, a reoperációt megelőzően.

A referáló intézményekben halasztott ellátás tervével posztoperatívan 1 sutura, $7 \mathrm{Kehr}$-drainage és 1 hepatico-jejunostomia történt. A sutura az epehólyagágyat érintette. Intézetünkben mindegyik esetben reoperációra került sor hepatico-jejunostomia formájában. A sutura és a $7 \mathrm{Kehr}$-drainage után Intézményünkben 5 diagnosztikus ERCP-vizsgálatot végeztünk preoperatívan.

Klinikánkra áthelyezett betegek halasztott ellátása, nem a primeren operáló helyen, 8 esetben történt: 7 esetben ERCP volt az elsődleges intervenció, melyet mindegyik esetben hepatico-jejunostomia követett. Egy esetben pedig az átvétel utáni - ERCP nélkül - azonnali biliodigestív anasztomózis elkészítése jelentette a végső megoldást (5. ábra).

Összegezve tehát a 37 reoperáció közül 65\%-ban (24/37) hepatico-jejunostomia, 27\%-ban (10/37) Kehrdrainage és $8 \%$-ban sutura történt (3/37). A klinikán fellépő epeúti sérülés és a megoldást jelentő beavatkozás között átlagosan 7 nap telt el, míg a más intézetekből áthelyezett betegek esetében ez az idő átlagosan 26 napra tehetö.

Az epeúti sérült betegek kapcsán összesen 25 ERCP történt. Egy esetben volt sikertelen a Vater papilla kanülálása. Tizenkét esetben történt stentimplantáció és 13 esetben csupán diagnosztikus ERCP. A Strasberg-féle klasszi- fikáció alapján „A” csoportba jutó 12 beteg közül 10 (83\%) esetben az ERCP és a stentbehelyezés a végső terápiát jelentette, tehát az epecsorgás megszünését.

A szövődményes betegek 8\%-ánál (6/78) jelentkezett posztoperatívan icterus. Ezekben az esetekben a terápiás és egyben diagnosztikus lépés elsősorban az ERCP volt. 3 esetben volt terápiás az EST, amelyek közül 1 esetben kőextrakció is történt. 2 esetben bizonytalan etiológiájú epeúti szükület volt valószínüsíthető, ezek közül 1 eset alkalmával volt stentbehelyezés, és 1 másik eset során a diagnosztikus ERCP során érdemi szükület nem igazolódott, a beteg icterusa spontán megszünt. Végül 1 eset során reoperáció történt Kehr-drainage formájában. Tehát a 6 posztoperatív icterus esetén $5(83 \%)$ esetben nemcsak diagnosztikus jelentősége volt az ERCP-nek, de a definitív terápiát is jelentette.

$\mathrm{Az}$ epeúti sérülések rekonstrukciója után 90 napon belüli szövődményként 4 esetben lépett fel subhepaticus folyadék, 2 esetben cholangitis, szintén 2 esetben lázas állapot és sebsuppuráció. Ileus, felső gasztrointestinális vérzés, szabad hasi folyadék peritonitissel, Clostridium difficile-fertőzés, májtályog, anaemia és pneumonia 1-1 alkalommal jelentkezett. A 90 napon túli morbiditást vizsgálva 6 esetben volt szükség re-hepaticojejunostomia elvégzésére, ezeket megelőzően 3 esetben történt percutan epeúti drainage (PTD). Egy Kehr-drainage mütét után volt szükség ismételt reoperációra strangulatios ileus miatt. A 3 PTD elvégzése mindegyik esetben icterus miatt volt indokolt. 2 esetben külső drainaget, míg egy esetben külső és belső drainaget is alkalmaztunk. A 6 re-hepaticojejunostomia közül 4 alkalommal stenosis lépett fel, amelyek közül egy esetben leírtak cholestasist és cholangitist is, míg egy másik alkalommal choledocholithiasist. A maradék két esetben a bal májlebeny epeelfolyási akadálya állt fent, aminek a hátterében egy alkalommal hepaticolithiasis állt. A 90 napon túli re-hepaticojejunostomiák kizárólag az átvett betegcsoportból kerültek ki (6. ábra).

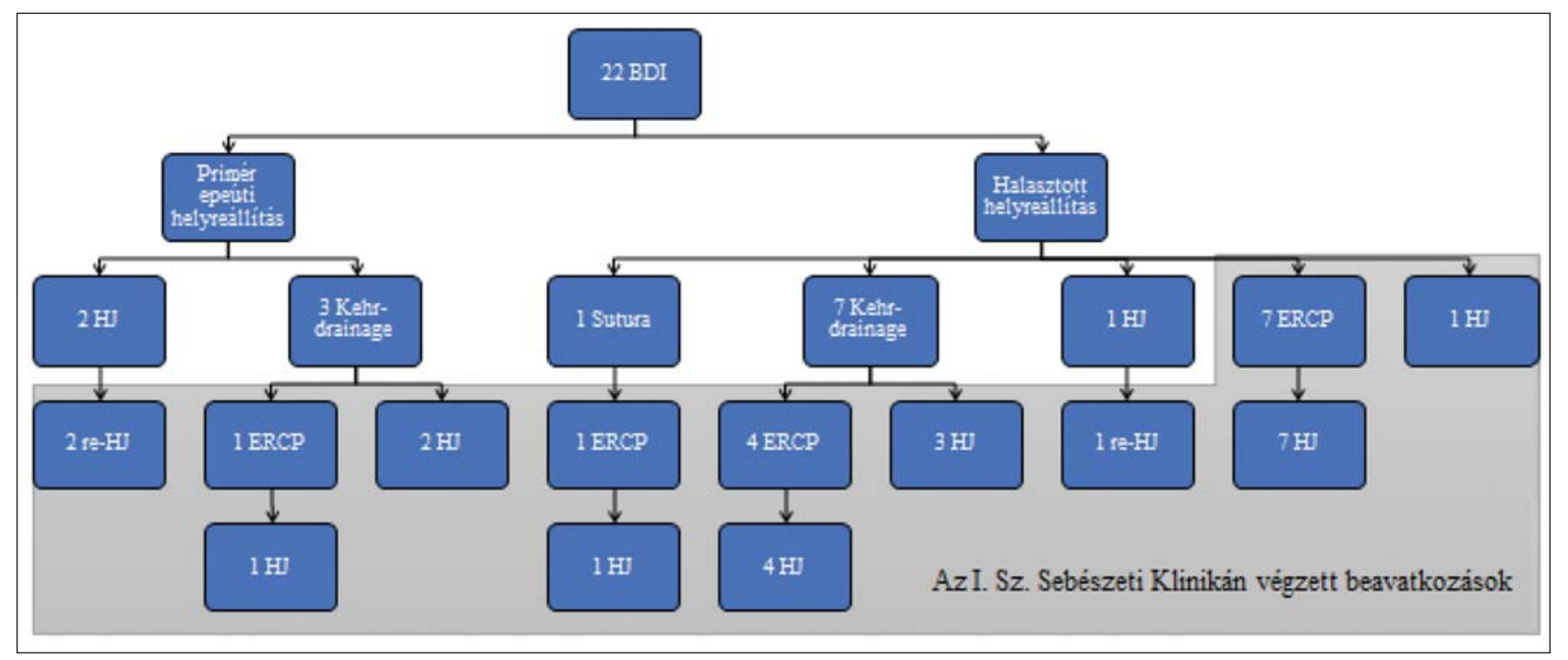

5. ábra. Az áthelyezett epeúti sérülések ellátása 


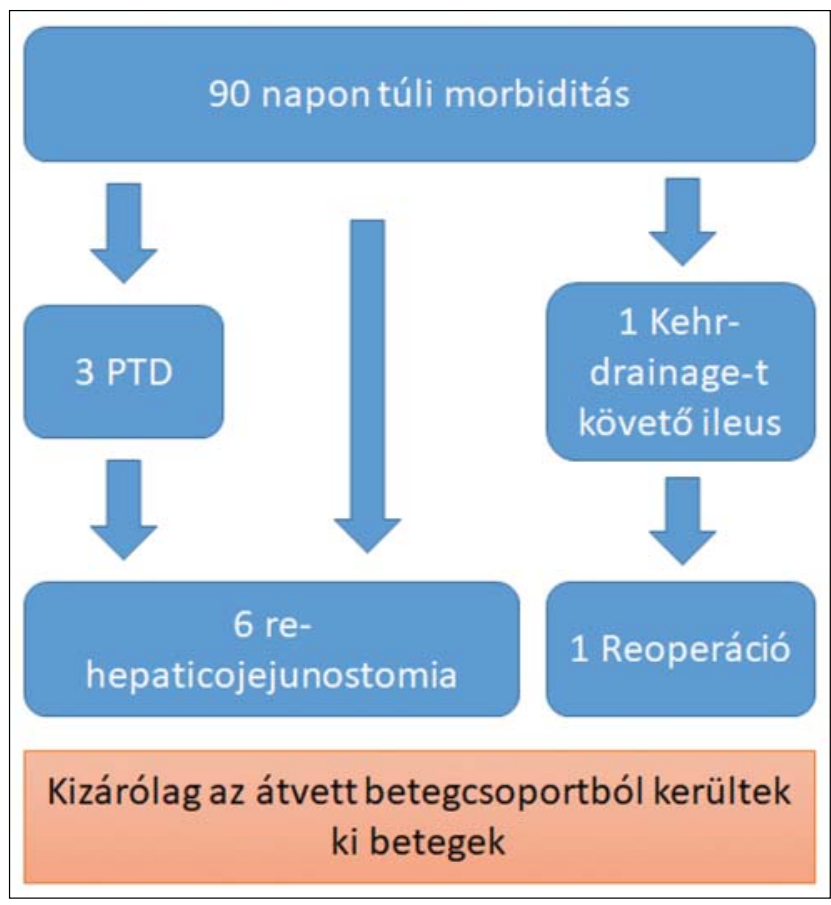

6. ábra. 90 napon túli morbiditás

\section{Megbeszélés}

A biliáris megbetegedések, mint az epehólyag-, illetve epeúti kövesség és következményes gyulladás a leggyakoribb, sebészi ellátást igénylő kórképek egyike. A cholecystolithiasis kezelésében a laparoszkópos cholecystectomia alapvető szerepet tölt be, ami így a legnagyobb számban alkalmazott mütétek közé tartozik. Az Egyesült Államokban közel egymillió laparoszkópos epehólyageltávolítás történik évente. Magyarország teljes területére vonatkozó friss adat nem elérhető, azonban egy tercier centrumban, mint a Semmelweis Egyetem I. sz. Sebészeti Klinikáján, az éves beavatkozásszám átlagban eléri a 450 -et. ${ }^{1}$

Az LC ugyan rutinbeavatkozásnak tekinthető, ugyanakkor irodalmi adatok alapján a beavatkozást követő epeúti sérülések incidenciája 0,1-2\%-ra tehető. A Semmelweis Egyetem I. sz. Sebészeti Klinikáján a vizsgált időperióduson belül az LC-k, valamint konvertált LC-k 0,3\%-ában fordult elő epeúti és érsérülés, ami megfelel a fenti nemzetközi adatoknak, ugyanakkor erre vonatkozó országos adatok nem állnak rendelkezésre. ${ }^{1}$

Az epeúti léziók jelentőségét mutatja, hogy számos, a sérülést leíró klasszifikáció jelent meg az elmúlt évtizedekben. Miután klinikánkon elhanyagolható számban fordul elő érsérülés, ezért vizsgálatunkban az epeútsérülés módját és anatómiai sajátosságát alapul vevő Strasberg-klaszszifikációt alkalmaztuk. A megfigyelési időszakban az epeúti léziók döntő többsége az „E” kategóriába tartozott. Egy nemrégiben megjelent nemzetközi multicentrikus tanulmány alapján - hasonlóan saját kutatásunkhoz - az epeúti sérülések legnagyobb százaléka (83\%) szintén ebbe a kategóriába tartozik. A második legnagyobb arányban előforduló lézió a ductus cysticus sérülés (Strasberg „A”). E két gyakoribb sérülés oka feltételezhetően a Calot-háromszög nem megfelelö kipreparálása és a cyticuscsonk elégtelen ellátása, amely így a ductus cysticus szivárgásához (Strasberg „A”), vagy az anatómiai képletek tévesztése esetén a ductus choledochus epeutak sérüléséhez (Strasberg „D” és „E”) vezethet. A fenti súlyos szövődmények azonban elkerülhetőek a Calot-háromszög képleteinek kritikus azonosításával, a „Critical View of Safety” szabályainak korrekt alkalmazásával. Sürgösségi mütéti ellátás során, a gyulladás következtében gyakran nehezen vagy egyáltalán nem azonosítható képletek esetén alternatív mütéti technikák (anterográd cholecystectomia, subtotalis cholecystecomia, cholecystotomia) alkalmazásával fokozható a biztonság, melyre vonatkozólag számos irodalmi ajánlás olvasható. A „B” és „C” csoportba tartozó sérülések csekély előfordulásának oka nagy valószínűséggel az anatómiai variáció és az epeúti sérülés együttes meglétének alacsony esélye. ${ }^{4-7}$

Az epeúti sérülések legföbb diagnosztikus eszköze az ERCP. Megjegyzendő, hogy az epeúti diagnosztika fegyvertárában alapvető az MRCP, de az endoszkópos módszer nagy előnye, hogy a diagnózis mellett gyakran terápiás megoldást is jelenthet. A ductus cysticust érintő epeúti sérülések tekintetében (Strasberg „A”) az ERCP az esetek jelentős részében egyúttal végső terápiát is jelentheti $(83 \%$, 10/12). Kutatásunk és az irodalmi adatok alapján tekintettel arra, hogy a ductus cysticus sérülése az epeúti sérülések szignifikáns hányadát alkotja, úgy tünik, hogy az összes epeúti sérülés jelentős része minimál invazív endoszkópos beavatkozással ellátható. Irodalmi adatok alapján a súlyosabb sérülések, mint a ductus hepaticus communis és a ductus choledochus szivárgásainak $80 \%$-a endoszkóposan szintén kezelhető, azonban az ezután is perzisztáló epecsorgás mütéti javallatot jelent. ${ }^{7-18}$

Amennyiben az ERCP nem jelentett terápiás megoldást, úgy mütéti beavatkozás szükséges. Az irodalomban számos mütéti rekonstrukciós technika leírásra került, melyek közül kiemelendő a biliodigesztív anastomosis és a sérült epeút aláöltése vagy Kehr-cső feletti direkt varrata. Ductus cysticus szivárgás esetében a csonk aláöltése általában a probléma megoldását jelenti. Kiterjedt epeúti sérülések esetén azonban Kehr-cső feletti sutura vagy anastomosis képzése javasolt. Általánosságban elmondható, hogy kiterjedt szövetkárosodással nem járó Strasberg „B”, „C”, „D” és „E” sérülések esetén, amennyiben az adott intézmény hepatobiliaris sebészetben nem jártas, úgy Kehr-drainage, míg kiterjedt lézió esetében biliodigesztív anastomosis javasolható. Az irodalmi adatok alapján a részleges epeúti sérüléseket nagyobb százalékban (69\%) kezelik suturázással, míg az epeutak teljes átmetszésének rekonstrukciójánál a biliodigesztív anastomosisok dominálnak (63\%). Kehr-drainage után azonban nagyobb arányban kell rövid, illetve hosszú távú szövődményekkel számolnunk, melyek közül kiemelendő a beteg életminőségét jelentősen befolyásoló, gyakran nehezen kezelhető epeúti szükület. Saját vizsgálati eredményeink alapján is elmondható, hogy a 
más intézményből átvett betegek esetében, amennyiben a sérülés primer ellátása Kehr-drainage segítségével történt, úgy valamennyi esetben ismételt mütétre, hepatico-jejunostomiára került sor. ${ }^{19-21}$

Azon eseteknél, ahol a sérülést nem sikerült a primer intézményben megfelelően ellátni és a beteget a tercier progresszivitású intézménybe szállíttatták, az epeúti sérülés sokkal komplexebb ellátást igényelt. Ezen esetekben a diagnózis és az epeúti rekonstrukció között átlagosan 26 nap telt el. A rekonstrukciót követő 90 napon túl, reoperáció 6 alkalommal, PTD 3 alkalommal vált szükségessé. Amennyiben az epeúti sérülés és a primer ellátás olyan intézményben történt, amely rendelkezett a szükséges szakmai és technikai háttérrel, úgy a betegút sokkal kevésbé volt komplikált, és a rekonstrukció 7 napon belül megtörtént. Ezen betegek esetében további, súlyos, reoperációt szükségessé tevő szövődmény nem lépett fel. Úgy tünik tehát, hogy a diagnózis ideje és a reoperáció között eltelt idő kritikus a korai és késői morbiditás szempontjából. Megjegyzendő azonban, hogy a más intézményből beutalt betegek feltehetőleg a legkomplikáltabb esetek, így ez is indokolhatja a komplexebb ellátás nagyobb igényét. Az epeúti sérülés csekély előfordulása miatt, még egy országos centrumban, mint a Semmelweis Egyetem I. sz. Sebészeti Klinikáján is, alacsony az esetszám nagyszabású összehasonlító statisztikai próbák végzéséhez. Leíró jellegü tanulmányunkból azonban látszik a korai, illetve késői rekonstrukció kérdésének fontossága. Megjegyzendő, hogy a nemzetközi irodalmi adatok alapján az intraoperatív és a késői (6 héten túli) rekonstrukció kimenetele között nincs szignifikáns különbség. ${ }^{5}$

Az epeúti sérülések optimális ellátása nyilvánvalóan csak tapasztalt hepatobiliáris sebész által, tercier centrumban lenne lehetséges. Ugyanakkor, mivel a cholecystectomiákat alacsonyabb progresszivitású központokban is végzik, és a sérülések felismerése és ellátása sokszor már a primer mütét során megtörténik, ez csak az esetek töredékében történhet meg. Így a sikeres kimenetelhez egyidejüleg lenne szükséges a sérülés azonnali felismerése valamint optimális mútéti ellátása, másrészt a legnagyobb gyakorlattal rendelkező centrumba való mielöbbi referálás. A kettős, elvi követelménynek egyszerre lehetetlen eleget tenni. A step-up megközelítést szem elött tartva ugyanakkor először mindenképpen a legkevésbé invazív beavatkozással érdemes az epeúti sérülést kezelni.

Kiemelt szerepet kap az ellátásban az invazív endoszkópia, amely nem csak a diagnosztikában nyújthat segítséget, de szerencsés esetben a végső terápiás megoldást is jelentheti. A komplikált esetek ellátása tehát csak a megfelelő rutinnal és háttérrel rendelkező intézményekben javasolt. A beteg csak akkor óvható meg a további felesleges megterhelésektől, illetőleg a szövődményes esetek ellátása akkor optimalizálható, ha a rendszeres és egységes betegtájékoztatás és betegvezetés mellett a gasztroenterológus, a radiológus és a sebész egy multidiszciplináris csapatként dolgozik. ${ }^{17,22-28}$

\section{Irodalomjegyzék}

${ }^{1}$ Barrett M, Asbun HJ, Chien HL, Brunt LM, Telem DA: Bile duct injury and morbidity following cholecystectomy: a need for improvement. Surg Endosc. 2018; 32(4): 683-688.

${ }^{2}$ Gtuszek S, Kot M, Batchanowski N, Matykiewicz J, Kuchinka J, Koziet D, Wawrzycka I: Iatrogenic bile duct injuries - clinical problems. Polski Przeglad Chirurgiczny 2014; 86(1): 17-25.

${ }^{3}$ Hori T, Oike F, Furuyama H, Machimoto T, Kadokawa Y, Hata T, Kato S, Yasukawa D, Aisu Y, Sasaki M, Kimura Y, Takamatsu Y, Naito M, Nakauchi M, Tanaka T, Gunji D, Nakamura K, Sato K, Mizuno M, Iida T, Yagi S, Uemoto $S$, Yoshimura T: Protocol for laparoscopic cholecystectomy: Is it rocket science? World Journal of Gastroenterology 2016; 22(47): 10287-10303.

${ }^{4}$ Chun K: Recent classifications of the common bile duct injury. Korean J Hepatobiliary Pancreat Surg 2014; 18(3): 69-72.

${ }^{5}$ Manatakis DK, Papageorgiou D, Antonopoulou MI, Stamos $N$, Agalianos $C$, Ivros N, Davides D, Pechlivanides $G$, Kyriazanos I: Ten-year audit of safe bail-out alternatives to the critical view of safety in laparoscopic cholecystectomy. World J Surg. 2019; 43(11): 2728-2733.

${ }^{6}$ Wakabayashi G, Iwashita Y, Hibi T, Takada T, Strasberg SM, Asbun HJ, Endo I, Umezawa A, Asai K, Suzuki K, Mori Y, Okamoto K, Pitt HA, Han HS, Hwang TL, Yoon YS, Yoon DS, Choi IS, Huang WS, Giménez ME, Garden OJ, Gouma DJ, Belli G, Dervenis C, Jagannath P, Chan $A C W$, Lau WY, Liu KH, Su CH, Misawa T, Nakamura M, Horiguchi A, Tagaya N, Fujioka S, Higuchi R, Shikata S, Noguchi Y, Ukai T, Yokoe M, Cherqui D, Honda G, Sugioka A, de Santibañes E, Supe AN, Tokumura H, Kimura T, Yoshida M, Mayumi T, Kitano S, Inomata M, Hirata $K$, Sumiyama Y, Inui K,:Yamamoto M: Tokyo Guidelines 2018: surgical management of acute cholecystitis: Safe steps in laparoscopic cholecystectomy for acute cholecystitis (with videos). J Hepatobiliary Pancreat Sci. 2018; 25(1): 73-86.

7 Bergman JJ, al. (1996) "Treatment of bile duct lesions after laparoscopic cholecystectomy." Gut. 38(1): 141-147.

${ }^{8}$ Bergman JJ, van den Brink GR, Rauws EA, de Wit L, Obertop H, Huibregtse K, Tytgat GN, Gouma DJ: Treatment of bile duct lesions after laparoscopic cholecystectomy. Gut 1996; 38(1): 141-147.

${ }^{9}$ Barauskas G, Paškauskas S, Dambrauskas Z, Gulbinas A, Pundzius J: Referral pattern, management, and longterm results of laparoscopic bile duct injuries: A case series of 44 patients. Medicina (Kaunas) 2012; 48(3): 138-144.

${ }^{10}$ Chinnery GE, Krige JE, Bornman PC, Bernon MM, Al-Harethi S, Hofmeyr S, Banderker MA, Burmeister $S$, Thomson SR: Endoscopic management of bile leaks after laparoscopic cholecystectomy. S Afr J Surg. 2013; 51(4): 116-121. 
${ }^{11}$ Cuendis-Velázquez A, Morales-Chávez C, Aguirre-Olmedo I, Torres-Ruiz F, Rojano-Rodríguez M, FernándezÁlvarez L, Cárdenas-Lailson E, Moreno-Portillo M: Laparoscopic hepaticojejunostomy after bile duct injury. Surg Endosc. 2016; 30(3): 876-882.

12 Fatima J, Barton JG, Grotz TE, Geng Z, Harmsen WS, Huebner M, Baron TH, Kendrick ML, Donohue JH, Que $F G$, Nagorney DM, Farnell MB: Is there a role for endoscopic therapy as a definitive treatment for post-laparoscopic bile duct injuries? J Am Coll Surg. 2010; 211(4): 495-502.

${ }^{13}$ Fong ZV, Pitt HA, Strasberg SM, Loehrer AP, Sicklick $J K$, Talamini MA, Lillemoe KD, Chang DC; California Cholecystectomy Group: Diminished survival in patients with bile leak and ductal injury: Management strategy and outcomes. J Am Coll Surg. 2018; 226(4): 568-576. e1

${ }^{14}$ Hajjar NA, Tomuş C, Mocan L, Mocan T, Graur F, Iancu $C$, Zaharie $F$ : Management of bile duct injuries following laparoscopic cholecystectomy: long-term outcome and risk factors infuencing biliary reconstruction. Chirurgia (Bucur). 2014; 109(4): 493-499.

${ }^{15}$ Lo Nigro C, Geraci G, Sciuto A, Li Volsi F, Sciume C, Modica $G$ : Bile leaks after videolaparoscopic cholecystectomy: duct of Luschka. Endoscopic treatment in a single centre and brief literature review on current management. Ann Ital Chir. 2012; 83(4): 303-312.

${ }^{16}$ Renz $B W$, Bösch F, Angele $M K$ : Bile duct injury after cholecystectomy: Surgical therapy. Visc Med. 2017; 33(3): 184-190.

17 Thompson CM, Saad NE, Quazi RR, Darcy MD, Picus $D D$, Menias $C O$ : Management of iatrogenic bile duct injuries: role of the interventional radiologist. Radiographics 2013; 33(1): 117-134.

18 Strasberg S. M: A three-step conceptual roadmap for avoiding bile duct injury in laparoscopic cholecystectomy: an invited perspective review. Journal of Hepato-Biliary-Pancreatic Sciences 2019; 26(4): 123-127.

${ }^{19}$ Martin D, Uldry E, Demartines N, Halkic $N$ : Bile duct injuries after laparoscopic cholecystectomy: 11-year experience in a tertiary center. Biosci Trends. 2016; 10(3): 197-201

${ }^{20}$ Ihász M, Regöly-Mérei J, Szeberin Z, Bátorfi J, Fazekas T, Máté M: A laparoscopos cholecystectomia és az epeútsérülések. 26.440 hazai mütét tapasztalatainak elemzése. Orv Hetil. 1996; 137(18): 955-963.
${ }^{21}$ Conzo G, Amato G, Angrisani L, Bardi U, Barone G, Belli $G$, Brancaccio U, Calise F, Caliendo A, Celsi S, Corcione $F$, Cuccurullo D, De Falco G, Delrio P, De Werra C, De Sena $G$, Docimo $G$, Esposito $M G$, Fantini $C$, Giardiello C, Musella M, Molino C, Muto C, Pennetti L, Puziello A, Porcelli A, Rea R, Rendano F, Palazzo A, Santangelo $M$, Santaniello $W$, Santini L, Sperlongano P, Stanzione F, Tartaglia A, Tricarico A, Vincenti R, Lorenzo M: Surgical treatment of iatrogenic bile duct injuries following laparoscopic cholecystectomy: analysis of long-term results. Retrospective clinical study in 51 patients operated in the Campania region from 1991 to 2003. Chir Ital. 2005; 57(4): 417-424.

${ }^{22}$ Bobkiewicz A, Krokowicz L, Banasiewicz T, Kościński T, Borejsza-Wysocki M, Ledwosiński W, Drews M: Iatrogenic bile duct injury. A significant surgical problem. Assessment of treatment outcomes in the department's own material. Pol Przegl Chir. 2015; 86(12): 576-583.

23 de Reuver PR, Rauws EA, Bruno MJ, Lameris JS, Busch OR, van Gulik TM, Gouma DJ: Survival in bile duct injury patients after laparoscopic cholecystectomy: a multidisciplinary approach of gastroenterologists, radiologists, and surgeons. Surgery. 2007; 142(1): 1-9.

${ }^{24}$ Kerimoglu RS, Bostanci EB, Dalgic T, Karaman $K$, Kayapinar AK, Ozer I, Ulas M, Ozogul YB, Akoglu M: Management of laparoscopic cholecystectomy-related bile duct injuries: A tertiary center experience. Arch Iran Med. 2017; 20(8): 487-493.

${ }^{25}$ Mercado MÁ, Franssen B, Dominguez I, Arriola-Cabrera JC, Ramírez-Del Val F, Elnecavé-Olaiz A, Arámburo-García R, García A: Transition from a low: to a high-volume centre for bile duct repair: changes in technique and improved outcome. HPB (Oxford) 2011; 13(11): 767-773.

${ }^{26}$ Pekolj J, Alvarez FA, Palavecino M, Sánchez Clariá R, Mazza $O$, de Santibañes E: Intraoperative management and repair of bile duct injuries sustained during 10,123 laparoscopic cholecystectomies in a high-volume referral center. J Am Coll Surg. 2013; 216(5): 894-901.

27 Slater K, Strong RW, Wall DR, Lynch SV: Iatrogenic bile duct injury: the scourge of laparoscopic cholecystectomy. ANZ J Surg. 2002; 72(2): 83-88.

${ }^{28} \mathrm{Wu} Y \mathrm{~V}$, Linehan DC: Bile duct injuries in the era of laparoscopic cholecystectomies. Surg Clin North Am. 2010; 90(4): 787-802.

A cikk a Creative Commons Attribution 4.0 International License (https://creativecommons.org/licenses/by/4.0/) feltételei szerint publikált Open Access közlemény, melynek szellemében a cikk bármilyen médiumban szabadon felhasználható, megosztható és újraközölhetö, feltéve, hogy az eredeti szerző és a közlés helye, illetve a CC License linkje és az esetlegesen végrehajtott módosítások feltüntetésre kerülnek. (SID_1) 